\title{
An Investigation into English Vocabulary Attrition among College Students of Non-English Majors in Inner Mongolia University for the Nationalities
}

\author{
Meihua Wang ${ }^{1}$ \\ ${ }^{1}$ School of Foreign Languages, Inner Mongolia University for the Nationalities, Tongliao, China \\ Correspondence: Meihua Wang, School of Foreign Languages, Inner Mongolia University for the Nationalities, \\ Huolinhe Street, Tongliao City, Inner Mongolia, P. R. China. Tel: 86-151-6490-1819. E-mail: \\ meihua_ehome@163.com
}

Received: August 4, 2014 Accepted: September 12, 2014 Online Published: November 25, 2014

doi:10.5539/ells.v4n4p62 URL: http://dx.doi.org/10.5539/ells.v4n4p62

\begin{abstract}
Since language attrition was formally recognized at the conference on the "Attrition of Language Skills" at the University of Pennsylvania in 1980, the past three decades saw the numerous studies and researches on it. Language attrition refers to a constant overall regression of language ability with decreased or ceased language use. Language attrition as the inverse process of language acquisition provides a brand-new perspective for language acquisition study. Thus, language acquisition study is incomplete without study on language attrition. Most of related researches and studies of language attrition have been finished in European, American and Japanese contexts. A good academic harvest is reaped by foreign scholars, such as Seliger, Sharwood, Bahrick, Hasan, Tomiyama, Gardner, Kopke, Lambet, Weltens and so forth. In China, despite of many achievements have been made in field of language attrition, little attrition has been paid to the language attrition study. Language attrition still stays at the theory-introducing stage. Empirical studies are sporadic. This paper will try to analyze English attrition degree from the perspective of vocabulary among college students of non-English majors in universities for nationalities, find whether attrition difference exists in English vocabulary, that is, which kind of words are more liable to be attrited.
\end{abstract}

Keywords: language attrition, English vocabulary, rate of attrition

\section{Introduction}

In the past, major emphasis was put on "what to learn", "how to learn" and "what has been learned" in the field of foreign language acquisition. Little attention was paid to "what to do after the acquisition" or "how to maintain the language proficiency once acquired". To a certain degree, no one can deny that their language proficiency declines to different extent after disuse of the language for a period. The effortless feeling pushes learners to wonder how to maintain language proficiency and improve their language skills. The main reason is that most learners stop using or seldom use the language once they finish their formal learning at school.

In china, many scholars have conducted their researches from the acquisition level to find the way to solve this problem. Actually much of their attention should be directed to language attrition. Comparing with the research on language acquisition, study on language attrition is a relatively new enterprise. This study falls into the domain of language attrition.

\section{Literature Review}

This part is composed of three sections. The first section is about the various definitions and classifications of language attrition. The second section presents two hypotheses relating with language attrition, namely, the Regression Hypothesis and the Selectivity Theory. The third section reviews studies on vocabulary attrition at the macro-level and the micro-level.

\subsection{Definition and Type of Language Attrition}

The conference "The Attrition of Language Skills", held at the University of Pennsylvania in 1980, provided a theoretical launching ground for the research in the field of language attrition. Lambert and Freed put forward a broad definition for language attrition "the loss of any language or any portion of a language by an individual or 
a speech community" (Lambert \& Freed, 1982, p. 1). After the reference, various definitions are made by scholars. Oxford claimed that "language loss" refers to loss or attrition of skill in one's native language (L1) or a second or foreign language (L2) (Oxford, 1982, p. 66). In Schmid's opinion, language attrition is "gradual loss of a language by an individual" (Schmid, 2002, p. 5). According to Hansen, language attrition is "the gradual forgetting of a language by individual attriters, who are experiencing attrition" (Hansen, 2001, p. 61). De Bot (2001) held that the term "attrition" was also used to refer to individual language loss and consequently took place within one generation. Kopke (2004) defines attrition as "non-pathological loss of a language in, usually, bilingual subjects". Gardner, Lalonde and MacPherson (1985) presented a more specific definition of the term when they narrowed it down to the range of second language use. They claimed that second language attrition refers to "the loss of proficiency in a second language due to lack of use over time". And this definition is specific to the present study.

De Bot, Weltens \& Van Els (1986) classified language attrition into four types on the basis of two factors: what language is lost (i.e. the L1 or L2) and the environment in which the language is lost (i.e., L1 or L2 environment). Type one refers to the loss of L1 in the L1 language, for example, dialect loss or aging. Type two refers to the loss of L1 in an L2 environment, for example, loss of the native language by immigrants. Type three is the loss of L2 in an L1 environment, for example, loss of school-learned foreign language. Type 4 is connected to the L2 attrition in an L2 environment, for example, the loss of L2 by aging immigrants. The present study which concentrates on the vocabulary attrition of English in the Chinese context falls into the type three, loss of L2 in L1 environment.

Two different views about the rate of attrition are offered, one is that attrition occurs quickly, but then the rate of attrition slows down; the other is that no obvious attrition occurs at the beginning followed by real attrition. The former pattern reflects the forgetting curve which is proved by studies of Kennedy and Bahrick. Kennedy maintained that attrition occurs quickly, but the rate declined exponentially in subsequent periods (Kennedy, 1932, pp. 132-146). Bahrick's studies show that attrition is significant after the first year of disuse and retention remained stable for more than 25 years. He found that there is a portion of the knowledge acquired in the L2 that is lost within a few years after training, but the reminder is immune to further losses for at least a quarter of a century, and much of that content survives for 50 years or longer (Bahrick, 1984, p. 111). On the other hand, other scholars believed in the existence of an initial plateau, that is, at the beginning subjects has a good retention and comprehension of second language skills, subsequently attrition occurs. Messlink and Verkuylen (1984) found no loss in the first year and about 15 percent loss in the second year of disuse. Cohen (1989) also found that significant L2 attrition occurs after nine months of disuse.

\subsection{Hypotheses Related to Language Attrition}

\subsubsection{The Regression Hypothesis}

The regression hypothesis, the first and well-known theory in explaining the nature of language attrition, is a most widely-accepted but controversial theory. Ribot brought the concept into being in 1880s. And Freud adopted his idea to analyze pathological language attrition. In 1941, Jakobson proposed the Regression Hypothesis as he was studying on pathological case of language attrition. He maintained that the attrition process and the acquisition process were opposite to each other. This hypothesis involves two version: one is reserve order based on chronology which holds that the order in which attrition occurs is opposite to the order in which language was acquired; the other is inverse relation hypothesis based on reinforcement which maintains that what has been learned best, that is, most often used or reinforced, will be resistant to loss (Yoshitomi, 1992, pp. 293-318). Kopke and Schmid (2002) claimed that the Regression Hypothesis is two separate but related hypotheses which are based on chronology and reinforcement respectively. All in all, the Regression Hypothesis means the forms that are acquired late are more vulnerable to attrition, and the forms that are learned early are less vulnerable to attrition.

Many researchers (Jordens, de Bot, Van Os, \& Schumans, 1986; Jordens, de Bot, \& Trapman, 1989; Kuhberg, 1992; Olshtain, 1989; Schmid, 2002, cited in Kopke, 2004) have conducted numerous researchers that are congruent with the Regression Hypothesis. However, it is also found that this hypothesis cannot explain all cases of observed language loss (Caramazza \& Zurif, 1978; Hyltenstam \& Viberg, 1993) and does not hold true in connected with aphasia.

\subsubsection{The Selectivity Theory}

Selectivity is one of the attributes of language attrition and occurs in lots of aspects, including lexical knowledge, phonology, morpho-snytax, word class, word length, semantic loading, negation and so forth. It has been proved that some linguistic aspects are less immune to attrition. Bahrick (1984) stated that receptive vocabulary was 
more susceptible to attrition than productive vocabulary. Cohen (1989) and Yoshitomi (1992) found that productive skills tend to be lost than receptive skills. De Bot and Weltens (1991) found through study of L1 that low-frequency words are liable to be lost than high-frequency words. De Groot and Keijzer (2000) proposed that abstract words are easier to undergo attrition compared with concrete words. Ghasemi Begherabadi (2005) found verbs were more susceptible to attrition than nouns.

\subsection{A Review of Studies on Vocabulary Attrition}

Among all the language sub-skills, it can be broadly acknowledged that lexical knowledge is one of those most probably suffer attrition. As the largest area of linguistic knowledge, vocabulary is the area affected most by attrition, both in individual and in communities. Therefore, many scholars devote their rapt attention to vocabulary or lexical attrition.

On the basis of different research focuses, studies on vocabulary attrition could be roughly classified into two groups. On the one hand, researchers concentrate on vocabulary attrition at the macro-level, i.e. if vocabulary attrition took place, or to what degree vocabulary is attrited. On the other hand, researchers are devoted to vocabulary at the micro-level, i.e. a comparison of vocabulary attrition with attrition of other subsystems of language, or a comparison of attrition of subsystems within lexicon.

The major findings of previous vocabulary attrition researches can be summarized as follows. Firstly, some certain elements of a language are more susceptible to suffer attrition than others. Despite of some contradictory result, it is often assumed that vocabulary is more vulnerable to attrition than phonology and morpho-syntax. Secondly, nouns are assumed to be less susceptible to attrition than verbs, and within the group of nouns, it is much easier for specific nouns to undergo attrition than general ones. Thirdly, whether a word is a content word or a function word has little influence on the attrition of vocabulary. Fourthly, frequency is taken as an important factor that affects vocabulary attrition. Low frequency words are remembered poorly compared with those high frequency words. Finally, noncognates are more vulnerable to attrition than cognates.

The present study belong to the macro-level research, to be specific, it is designed to study the attrition of English vocabulary among college students in universities for nationalities. It is hoped that the research area could be broadened.

\section{Methodology}

This part is an introduction of the research methodology of the present study. To begin with, research questions, subjects, research instruments are to be presented. Then, the last two sections are to deal with how data are collected and analyzed.

\subsection{Research Questions}

The present study is designed to study the attrition of English vocabulary among college students in universities for nationalities. The aim of this study is to address the following questions.

1) To what extent college students lose their vocabulary after one year's disuse?

2) Are vocabulary acquired at middle school level and college level attired at the same rate? Will Regression hypothesis justify the attrition of English vocabulary learned in Chinese context?

3) Is certain type of vocabulary more susceptible to attrition?

\subsection{Subjects}

For the present study, 64 sophomores and 66 juniors majoring in clinical medicine were selected from Inner Mongolia University for the Nationalities as the subjects on the basis of convenient sampling method. The background of the two groups of subjects is similar. All of them have attended the National College Entrance Examination and their English is above the passing grade. They all share the same course books and English teacher.

Table 1. Background information of the subjects $(\mathrm{N}=130)$

\begin{tabular}{lllll}
\hline Group & Number & Male & Female & Mean age \\
\hline Sophomore & 64 & 30 & 34 & 20.3 \\
Junior & 66 & 32 & 34 & 21.26 \\
\hline
\end{tabular}




\subsection{Instruments}

A vocabulary test and a questionnaire are employed in the study. The questionnaire aims at investigating subjects' personal information. Their name, age, gender, major, English score for college entrance examination and their starting age of English learning are required to be filled in the blanks. The vocabulary test, designed by Prof. Ma is adopted in the present study (2009). There are seventy words in total in the form of multiple choices mixed with blank filling. The four choices are modified from the vocabulary knowledge scale created by Paribakht and Wesche.

Table 2. Vocabulary test

\begin{tabular}{|c|c|}
\hline A. & I don't think I have seen the word before. \\
\hline B. & this word before, but I don't know its meaning. \\
\hline C. & I have seen this word before, its meaning is _.. \\
\hline D. & I know several meanings of this word, e.g. 1)_2) \\
\hline
\end{tabular}

Test-takers make their choices based on how well they know a word. Choice A and B don't need any redundant explanation. If they know the word, they need to fill one Chinese equivalent at the end of choice $\mathrm{C}$. If a test taker is very familiar with the word and know more than one Chinese meaning, they are expected to write them all down at the end of choice D.

\subsection{Data Collection}

The test was administered in December, 2013, which is the end of the semester. Sophomores were to fulfill their formal English learning in about two weeks. Juniors have finished their college English study a year ago. Test-takers are required to finish the test within one hour and are not allowed to resort to such help as classmates, dictionary, computer and teacher. 130 papers are distributed and 130 returned, with a response rate of $100 \%$.

\subsection{Data Analysis}

All the collected date was put into computer for statistic analysis by using the software SPSS 13.0. As for the result of vocabulary test, if the answer is wrong, it will be regarded as column B. If only one answer is right in column D, it will be regarded as column C. Descriptive statistics, independent samples-test and correlation analysis are applied to determine the attrition rate and difference existing in vocabulary types.

\section{Result and Discussion}

This part presents the results of the present study based on date analysis. A variety of statistical analysis and descriptive analysis are used with a view to comparing the result. Then according to the result of this study, the three research questions are to be discussed.

\subsection{Result of the Study}

\subsubsection{Rate of Attrition}

As is showed in the following table, sophomores get 35.89 words correct on average, while juniors 29.12 words correct.

Table 3. Result of the vocabulary test

\begin{tabular}{llllll}
\hline Group & $\mathrm{N}$ & Minimum & Maximum & Mean & Std. Deviation \\
\hline Sophomore & 64 & 15 & 68 & 35.89 & 10.11 \\
Junior & 66 & 7 & 56 & 29.12 & 10.12 \\
\hline
\end{tabular}

Nineteen percent loss of vocabulary is detected through the comparison of the average vocabulary size. As is displayed in the independent samples t-test, significant difference between the vocabulary sizes of two groups can be observed. With the significant difference level being 0.05 and the sig. value being $0.000(\mathrm{p}=0.000<0.05)$, it suggests two groups are statistically different. 
Table 4. Independent samples t-test for vocabulary size of different groups

\begin{tabular}{lllllll}
\hline & \multicolumn{2}{l}{$\begin{array}{l}\text { Levene's test for } \\
\text { equality of variances }\end{array}$} & \multicolumn{2}{l}{ t-test for equality of means } \\
\hline & $\mathrm{F}$ & $\mathrm{Sig}$ & $\mathrm{t}$ & $\mathrm{df}$ & $\mathrm{S}$ Sig(2-tailed) & Mean Difference \\
\cline { 2 - 7 } Equal Variances Assumed & 0.022 & .883 & 4.18 & 182 & 0.000 & 608.29 \\
Equal Variances Not Assumed & & & 4.17 & 156.98 & 0.000 & 608.29 \\
\hline
\end{tabular}

\subsubsection{Attrition Rate of Vocabulary Acquired at Different Stages}

According to the different learning stages, the seventy words can be divided into two groups, including 30 from middle school level and 40 from college level on the basis of the College English Curriculum Requirements. Then means and standard deviation of the accuracy of words is displayed in the following table.

Table 5. Means and Std. deviation for vocabulary learned at middle school

\begin{tabular}{llll}
\hline Group & $\mathrm{N}$ & Mean & Std. Deviation \\
\hline Sophomore & 64 & 20.38 & 4.79 \\
Junior & 66 & 17.19 & 5.48 \\
\hline
\end{tabular}

As is indicated in the above form, sophomores get 20.38 words correct, and it's only 17.19 words for juniors. The rate of attrition is $15.5 \%$.

Table 6. Independent samples t-test for vocabulary learned at middle school

\begin{tabular}{|c|c|c|c|c|c|c|}
\hline & \multicolumn{2}{|c|}{$\begin{array}{l}\text { Levene's test for } \\
\text { equality of variances }\end{array}$} & \multicolumn{4}{|c|}{ t-test for equality of means } \\
\hline & $\mathrm{F}$ & Sig & $\mathrm{t}$ & df & $\operatorname{Sig}(2$-tailed) & Mean Difference \\
\hline Equal Variances Assumed & 3.25 & 0.073 & 4.01 & 182 & 0.000 & 3.16 \\
\hline Equal Variances not Assumed & & & 3.76 & 138.73 & 0.000 & 3.16 \\
\hline
\end{tabular}

As for words acquired at the college level, the average accuracy for sophomore is 13.13 while the juniors 9.58, a loss of $26.6 \%$ of vocabulary.

Table 7. Means and Std. deviation for vocabulary acquired at college

\begin{tabular}{llll}
\hline Group & $\mathrm{N}$ & Mean & Std. Deviation \\
\hline Sophomore & 64 & 13.13 & 4.79 \\
Junior & 66 & 9.58 & 5.48 \\
\hline
\end{tabular}

As is demonstrated in the form below, the sig. value is $0.001<0.05$, showing the significant attrition of vocabulary learned at college.

Table 8. Independent samples t-test for vocabulary learned at college

\begin{tabular}{lllllll}
\hline & \multicolumn{4}{l}{$\begin{array}{l}\text { Levene's test for } \\
\text { equality of variances }\end{array}$} & \multicolumn{4}{l}{ t-test for equality of means } \\
\hline & $\mathrm{F}$ & $\mathrm{Sig}$ & $\mathrm{t}$ & $\mathrm{df}$ & $\mathrm{Sig}(2$-tailed) & Mean Difference \\
\cline { 2 - 7 } t-test for equality of means & 2.38 & 0.126 & 3.41 & 180 & 0.001 & 3.23 \\
t-test for equality of means & & & 3.52 & 169.75 & 0.001 & 3.23 \\
\hline
\end{tabular}

As for words acquired at the middle school level and college level, juniors suffer greater loss than sophomores. Vocabulary acquired at college is vulnerable to attrition than words learned in the middle school. This result also corresponds to the studies of Hasan who claims that certain first-learned language skills or elements are retained the longest. 


\subsubsection{Attrited Vocabulary and Retained Vocabulary}

\subsubsection{Attrition Rate of Different Word Classes}

In the present study, word class is restrained to noun, verb, adjective and adverb. The seventy words in the vocabulary test consist of 39 nouns, 11 verbs, 15 adjectives and 5 adverbs.

Table 9. Means and Std. deviation for vocabulary of different word classes

\begin{tabular}{lllll}
\hline Word class & Group & $\mathrm{N}$ & Means & Std. Deviation \\
\hline Noun & Sophomore & 64 & 17.12 & 5.03 \\
& Junior & 66 & 13.84 & 5.10 \\
Verb & Sophomore & 64 & 4.41 & 1.71 \\
& Junior & 66 & 3.37 & 1.71 \\
Adjective & Sophomore & 64 & 8.06 & 2.58 \\
& Junior & 66 & 6.42 & 2.64 \\
Adverb & Sophomore & 64 & 2.66 & 1.05 \\
& Junior & 66 & 2.01 & 0.93 \\
\hline
\end{tabular}

As is displayed in the above form, different word class has different attrition rate. Verbs suffer the most with $19 \%$ loss, nouns, $18 \%$ loss, adjectives, $18 \%$ loss, and adverbs, $17 \%$ of attrition. Attrition occurs to all word classes, only to a different degree. The following table indicates that significant attrition is detected in all word classes.

Table 10. Independent samples t-test for vocabulary of different word classes

\begin{tabular}{|c|c|c|c|c|c|c|c|}
\hline \multirow[t]{2}{*}{ Word class } & & \multicolumn{2}{|c|}{$\begin{array}{l}\text { Levene's test for } \\
\text { equality of variances }\end{array}$} & \multicolumn{4}{|c|}{ t-test for equality of means } \\
\hline & & $\mathrm{F}$ & Sig. & $\mathrm{t}$ & df & $\operatorname{Sig}(2$-tailed $)$ & Mean difference \\
\hline \multirow[t]{2}{*}{ Noun } & Equal variances assumed & 0.01 & 0.915 & 4.15 & 182.4 & 0 & 3.14 \\
\hline & Equal variances not assumed & & & 4.14 & 156.73 & 0 & 3.14 \\
\hline \multirow[t]{2}{*}{ Verb } & Equal variances assumed & 0.11 & 0.638 & 4.17 & 182.4 & 0 & 1.04 \\
\hline & Equal variances not assumed & & & 4.03 & 156.2 & 0 & 1.04 \\
\hline \multirow[t]{2}{*}{ Adjective } & Equal variances assumed & 0.19 & 0.667 & 4.13 & 182.4 & 0 & 0.63 \\
\hline & Equal variances not assumed & & & 4.05 & 157.3 & 0 & 0.63 \\
\hline \multirow[t]{2}{*}{ Adverb } & Equal variances assumed & 4.08 & 0.03 & 4.18 & 182.4 & 0 & 1.58 \\
\hline & Equal variances not assumed & & & 4.25 & 173.2 & 0 & 1.58 \\
\hline
\end{tabular}

\subsubsection{Attrition Rate between Active and Passive Vocabulary}

According to College English Curriculum Requirements, words can be categorized into active and positive words. Active words refer to words students should not only be able to comprehend, but also be able to use when expressing themselves in speaking or writing, while passive words are only required to know their meanings. The test includes 30 active words and 40 passive words. For the active words, the mean accuracy is 21 for sophomores and 18 for juniors with 14 percentage of attrition. For the passive words, the mean accuracy is 15 for sophomores and 11 for juniors with $27 \%$ of attrition.

Table 11. Means and Std. deviation for active and passive vocabulary

\begin{tabular}{lllll}
\hline Vocabulary & Group & $\mathrm{N}$ & Mean & Std. Deviation \\
\hline Active & Sophomore & 64 & 21.01 & 4.79 \\
& Junior & 66 & 17.94 & 5.49 \\
Passive & Sophomore & 64 & 15.12 & 4.79 \\
& Junior & 66 & 10.97 & 5.49 \\
\hline
\end{tabular}


Table 12. Independent samples t-test for active and passive vocabulary

\begin{tabular}{|c|c|c|c|c|c|c|c|}
\hline & & \multicolumn{2}{|c|}{$\begin{array}{l}\text { Levene's test for } \\
\text { equality of variances }\end{array}$} & \multicolumn{4}{|c|}{ t-test for equality of means } \\
\hline & & $\mathrm{F}$ & Sig & $\mathrm{t}$ & df & Sig.(2-tailed) & Mean difference \\
\hline \multirow[t]{2}{*}{ Active } & Equal variances assumed & .69 & .407 & 3.87 & 182.4 & .000 & 3.06 \\
\hline & Equal variances not assumed. & & & 3.80 & 149.23 & .000 & 3.06 \\
\hline \multirow[t]{2}{*}{ Passive } & Equal variances assumed & .22 & .638 & 3.50 & 182.4 & .000 & 3.36 \\
\hline & Equal variances not assumed & & & 3.61 & 160.75 & .000 & 3.36 \\
\hline
\end{tabular}

\subsection{Discussions}

Of the seventy tested words, sophomores get 35.89 words correct on average, while juniors 29.12 words correct. Nineteen percent loss of vocabulary is detected through a comparison of the average vocabulary size, which justifies apparent rate of vocabulary attrition in one-year of language disuse. This finding echoes the opinion of Cohen that significant $\mathrm{L} 2$ attrition occurs after nine months of disuse.

At the middle school level, sophomores get 20.38 words correct, while juniors 17.19 words correct. The rate of attrition is $15.5 \%$. Among 40 college words, the average accuracy for sophomores is 13.13 while the seniors 9.58 , a loss of $26.6 \%$ of vocabulary. Thus, we can make the conclusion that college vocabulary is more vulnerable to lose those acquired at middle school. This conclusion justifies the Regression Hypothesis which highlights that learners lose foreign language skills in an inverse order - attrition occurs opposite to the order in which language was acquired. To some extent, vocabulary acquired at middle school level are easier than that of college level, and they are repeated and used at a higher frequency, thus, they are retained better.

Selectivity is one of the attributes of language attrition. Different word class has different attrition rate. Verbs suffer the most with $19 \%$ loss, nouns, $18 \%$ loss, adjective, $18 \%$ loss, and adverbs, $17 \%$ of attrition. Attrition occurs to all word class, only with varying degrees of loss. However, no strict difference among different word class is observed from the present study. Besides, it is inappropriate to determine the rate of attrition of different word class in that the vocabulary test has only 70 words, not enough to come to a persuasive conclusion. For the active words, the mean accuracy is 21 for sophomores and 18 for juniors, with 14 percentage of attrition. For the passive words, the mean accuracy is 15 for sophomores and 11 for juniors, with 27 percentage of attrition. Thus we can come to the conclusion that passive words are more susceptible to lose than active words. Active words are required to be brought into use in speaking and writing, which can strengthen their retention. Passive words are not often used by learners, and attrition is inevitable.

\section{Conclusion}

This part is to present the main findings and pedagogical implications of the present study.

Firstly, attrition does occur among subjects with one-year disuse of English. This finding echoes Cohen's opinion that significant L2 attrition occurs after nine months of disuse. Secondly, we can draw the conclusion that college vocabulary is more vulnerable to lose those acquired at middle school. This conclusion justifies the Regression Hypothesis which highlights that learners lose foreign language skills in an inverse order. Thirdly, different word class experience different attrition rate. Certain word class is vulnerable to attrition, which proves the selective nature of language. However, no strict difference among different word class is observed from the present study.

Attrition is an inevitable phenomenon existing in foreign or second language acquisition. Knowledge of language attrition can generate great benefits to students and teachers of foreign or second languages to help them understand how the rate of loss is influenced by various procedures of acquisition, and thus it would eventually promote the process of establishing optimum conditions of retaining so as to minimize the potential for later attrition. In this case, the findings of this study have several pedagogical implications:

Firstly, the fact is that although many language teachers know how to teach and help students to be a good learner, they don't understand the importance of helping students retain their language skills after formal class training. Therefore, it is important and urgent for language attrition researchers to present foreign language teachers with a clear view of the long-term effects of their language teaching. For instance, in what length of time would language attrition appear, in what kind of situations would language attrition happen easier, which aspects of language skills are easier to suffer attrition, and so on. At the same time, researches of language attrition should provide language learners with not only theoretical but also practical basis for the retention of their language skills.

Secondly, as the length of period of disuse plays a role in vocabulary attrition and non-exposure to English 
endangers what they have already learned, college should add an English course during their fourth academic year in order to reinforce their vocabulary knowledge. In addition, students should be encouraged to relearn what they have learned by entering for a variety of English contests.

Thirdly, as active words are less vulnerable to attrition than passive ones, it is recommended that more emphasis be attached to training of passive words than active ones especially passive words in productive testing.

However, with a view to conclusively claiming such pedagogical implications, it is necessary to conduct further investigations into the effect of emphasis on these items which are more liable to attrition to see if such a focus will really make learners immune to attrition.

\section{References}

Bahrick, H. P. (1984). Fifty years of second language attrition: Implications for programmatic research. Modern Linguistics Journal, 68(2), 105-118. http://dx.doi.org/10.1111/j.1540-4781.1984.tb01551.x

Cohen, A. D. (1989). Attrition in the productive lexicon of two Portuguese third language speakers. Studies in Second Language Acquisition, 11(2), 135-150. http://dx.doi.org/10.1017/S0272263100000577

De Bot, K., \& Weltens, B. (1991). Recapitulation, regression and language loss. In H. W. Seliger \& R. M. Vago (Eds.), First language attrition (pp. 31-51). New York: Cambridge University Press.

De Groot, A., \& Keijzer, R. (2000). What is hard to learn is easy to forget: the roles of word concreteness, cognate status, and word frequency in foreign language learning and forgetting. Language Learning, 50(1), 1-56. http://dx.doi.org/10.1111/0023-8333.00110

Gardner, R. C., Lalonde, R. N., \& Macpherson, J. (1985). Social factors in second language attrition. Language learning, 35, 519-540.

Ghasemi B. M. (2005). L2 lexical attrition: Study of maintenance patterns after a break in instruction. Unpublished master thesis, University of Isfahan, Isfahan, Iran.

Hansen, L. (2001). Language attrition: The fate of the start. Annual Review of Applied Linguistics, 21, 60-73. http://dx.doi.org/10.1017/S0267190501000046

Hansen, L., \& Reetz-Kurashige. (1999). Investigating second language attrition: An introduction. In L. Hansen (Ed.), Second Language Attrition in Japanese Contexts (pp. 3-20). Oxford: Oxford University Press.

Jackobson, R. (1972). English Trans: Child Language, Aphasia, and Phonological universal. The Hague: Mouton Publishers.

Kennedy, L. (1932). The retention of certain Latin syntactical principles by first and second year Latin students after various time intervals. Journal of Educational Psychology, 132-146. http://dx.doi.org/10.1037/h0073426

Kopke, B. (2002). Activation thresholds and non-pathological L1 attrition. In E. Fabbro (Eds.), Advances in the Neurolinguistics of Bilingualism (pp. 119-142). Essays in Honor of Michel Paradis. Undine: Forum.

Köpke, B. (2004). Neurolinguistic aspects of attrition. Journal of Neurolinguistics, 17, 3-30. http://dx.doi.org/10.1016/S0911-6044(03)00051-4

Lambert, R. D. (1987). Language attrition. Paper presented at the AILA-8 $8^{\text {th }}$ World Congress of Applied Linguistics, Sydney: University of Sydney (printed (1989) in ITL Review of Applied Linguistics).

Lambert, R., \& Freed, B. (1982). The loss of language skills. Mass: Newbury House.

Lambert. R. D. (1989). Language attrition. Review of Applied Linguistics, 83, 1-18.

Messelink, J., \& Verkuylen, H. (1984). Het verlies Van woordenkennis Van het Frans. Doctoral Project, University of Nijmegen.

Oxford, R. L. (1982). Research on language loss: A review with implications for foreign teaching. The Modern Language Journal, 66, 160-169. http://dx.doi.org/10.1111/j.1540-4781.1982.tb06976.x

Schmid, M. S. (2002). First Language Attrition, Use and Maintenance: The Case of German Jew in Anglophone Countries. Amsterdam: Benjamin's.

Van Els, T. (1986). An Overview of European Research on Language Attrition. In B. Weitens, de Bot, \& T. Van Els (Eds.), Language Attrition in Progress (pp. 3-18). Dordrecht, Foris Publications.

Yoshitomi, A. (1992). Towards a model of language attrition: Neurobiological and psychological contributions. Issues in Applied Linguistics, 3(2), 293-318. 


\section{Appendix A}

\section{Vocabulary Test}

Make your choice based on your vocabulary knowledge

A. I don't think I have seen the word before.

B. I have seen this word before, but I don't know its meaning.

C. I have seen this word before, it meaning is

D. I know several meanings of this word, e.g. 1)_2) _ 3) _ 4) _.

\begin{tabular}{|c|c|}
\hline 1. applicant & 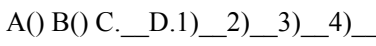 \\
\hline 2. building & $\left.\left.\left.\mathrm{A}() \mathrm{B}() \mathrm{C},[\mathrm{D} .1) \_2\right) \_3\right) \_4\right)$ \\
\hline 3. dryness & $\left.\left.\left.\mathrm{A}() \mathrm{B}() \mathrm{C} \cdot[\mathrm{D} \cdot 1) \_2\right) \_3\right) \_4\right)$ \\
\hline 4. existence & $\left.\mathrm{A}\left(\mathrm{)} \mathrm{B}\left(\mathrm{)} \mathrm{C} \cdot[\mathrm{D} \cdot 1) \_2\right) \_3\right) \_4\right)$ \\
\hline 5. gas & $\left.\left.\left.\mathrm{A}() \mathrm{B}() \mathrm{C},(\mathrm{D} \cdot 1) \_2\right) \_3\right) \_4\right)$ \\
\hline 6. hard & $\left.\left.\left.\mathrm{A}() \mathrm{B}() \mathrm{C} .[\mathrm{D} .1) \_2\right) \_3\right) \_4\right)$ \\
\hline 7. human & $\left.\left.\left.\mathrm{A}() \mathrm{B}() \mathrm{C} \cdot[\mathrm{D} \cdot 1) \_2\right) \_3\right) \_4\right)$ \\
\hline 8. musician & $\left.\left.\mathrm{A}() \mathrm{B}() \mathrm{C} .(\mathrm{D} .1) \_2\right) \_3\right)$ \\
\hline 9. paint & $\left.\left.\left.\mathrm{A}() \mathrm{B}() \mathrm{C},(\mathrm{D} \cdot 1) \_2\right) \_3\right) \_4\right)$ \\
\hline 10. redness & $\left.\left.\left.\mathrm{A}() \mathrm{B}() \mathrm{C} .(\mathrm{D} .1) \_2\right) \_3\right) \_4\right)$ \\
\hline 11. senselessness & $\left.\left.\left.\mathrm{A}() \mathrm{B}() \mathrm{C} \cdot(\mathrm{D} \cdot 1) \_2\right) \_3\right) \_4\right)$ \\
\hline 12. serious & $\left.\left.\left.\mathrm{A}() \mathrm{B}() \mathrm{C} \cdot[\mathrm{D} .1) \_2\right) \_3\right) \_4\right)$ \\
\hline 13. simplification & $\left.\left.\left.\mathrm{A}() \mathrm{B}() \mathrm{C} \cdot(\mathrm{D} \cdot 1) \_2\right) \_3\right) \_4\right)$ \\
\hline 14. table & $\left.\left.\left.\mathrm{A}() \mathrm{B}() \mathrm{C} .(\mathrm{D} \cdot 1) \_2\right) \_3\right) \_4\right)$ \\
\hline 15 . bushy & $\left.\left.\left.\mathrm{A}() \mathrm{B}() \mathrm{C} \cdot(\mathrm{D} \cdot 1) \_2\right) \_3\right) \_4\right)$ \\
\hline 16. defend & $\left.\left.\mathrm{A}() \mathrm{B}() \mathrm{C} .(\mathrm{D} .1) \_2\right)(3)-4\right)$ \\
\hline 17. host & $\left.\left.\left.\mathrm{A}() \mathrm{B}() \mathrm{C} .(\mathrm{D} \cdot 1) \_2\right) \_3\right) \_4\right)$ \\
\hline 18. hunger & $\left.\left.\left.\mathrm{A}() \mathrm{B}() \mathrm{C} \cdot[\mathrm{D} \cdot 1) \_2\right) \_3\right) \_4\right)$ \\
\hline 19. improve & $\left.\left.\left.\mathrm{A}() \mathrm{B}() \mathrm{C} \cdot(\mathrm{D} \cdot 1) \_2\right) \_3\right) \_4\right)$ \\
\hline 20. pain & $\left.\left.\left.\mathrm{A}() \mathrm{B}() \mathrm{C} \cdot[\mathrm{D} \cdot 1) \_2\right) \_3\right) \_4\right)$ \\
\hline 21. prisoner & $\left.\left.\left.\mathrm{A}() \mathrm{B}() \mathrm{C} .(\mathrm{D} \cdot 1) \_2\right) \_3\right) \_4\right)$ \\
\hline 22. selfish & $\left.\left.\left.\left.\mathrm{A}() \mathrm{B}() \mathrm{C} . \mathrm{D}_{2} \mathrm{D} \cdot 1\right) \_2\right) \_3\right) \_4\right)$ \\
\hline 23. treatment & $\left.\left.\left.\mathrm{A}() \mathrm{B}() \mathrm{C} \cdot(\mathrm{D} \cdot 1) \_2\right) \_3\right) \_4\right)$ \\
\hline 24. worm & $\left.\left.\mathrm{A}() \mathrm{B}() \mathrm{C} .(\mathrm{D} .1) \_2\right)(3)-4\right)$ \\
\hline 25. brevity & $\left.\left.\left.\mathrm{A}() \mathrm{B}() \mathrm{C} \cdot[\mathrm{D} \cdot 1) \_2\right) \_3\right) \_4\right)$ \\
\hline 26. corporate & $\left.\left.\left.\left.\mathrm{A}() \mathrm{B}() \mathrm{C} . \mathrm{D}_{2} \mathrm{D} \cdot 1\right) \_2\right) \_3\right) \_4\right)$ \\
\hline 27. indicator & $\left.\left.\left.\mathrm{A}() \mathrm{B}() \mathrm{C} .(\mathrm{D} \cdot 1) \_2\right) \_3\right) \_4\right)$ \\
\hline 28. linkage & $\left.\left.\left.\mathrm{A}() \mathrm{B}() \mathrm{C} \cdot[\mathrm{D} \cdot 1) \_2\right) \_3\right) \_4\right)$ \\
\hline 29. physically & $\left.\left.\left.\mathrm{A}() \mathrm{B}() \mathrm{C} \cdot[\mathrm{D} \cdot 1) \_2\right) \_3\right) \_4\right)$ \\
\hline 30. accent & $\left.\left.\left.\mathrm{A}() \mathrm{B}() \mathrm{C} .[\mathrm{D} .1) \_2\right) \_3\right) \_4\right)$ \\
\hline 31. airmail & $\left.\left.\left.\left.\mathrm{A}() \mathrm{B}() \mathrm{C} . \mathrm{D}_{1} \cdot 1\right) \_2\right) \_3\right) \_4\right)$ \\
\hline 32. prohibit & $\left.\left.\left.\mathrm{A}() \mathrm{B}() \mathrm{C} .[\mathrm{D} .1) \_2\right) \_3\right) \_4\right)$ \\
\hline 33. original & $\left.\left.\left.\mathrm{A}() \mathrm{B}() \mathrm{C} .[\mathrm{D} .1) \_2\right) \_3\right) \_4\right)$ \\
\hline 34. upper & $\left.\left.\left.\mathrm{A}() \mathrm{B}() \mathrm{C} \cdot[\mathrm{D} \cdot 1) \_2\right) \_3\right) \_4\right)$ \\
\hline 35. deregulation & $\left.\left.\left.\left.\mathrm{A}() \mathrm{B}() \mathrm{C} . \mathrm{D}_{1} \cdot 1\right) \_2\right) \_3\right) \_4\right)$ \\
\hline 36. evolutionist & $\left.\left.\left.\mathrm{A}() \mathrm{B}() \mathrm{C} \cdot[\mathrm{D} \cdot 1) \_2\right) \_3\right) \_4\right)$ \\
\hline 37. exclude & $\left.\left.\left.\mathrm{A}() \mathrm{B}() \mathrm{C} .[\mathrm{D} .1) \_2\right) \_3\right) \_4\right)$ \\
\hline 38. prime & $\left.\left.\left.\mathrm{A}() \mathrm{B}() \mathrm{C} .[\mathrm{D} .1) \_2\right) \_3\right) \_4\right)$ \\
\hline 39. principal & $\left.\left.\left.\mathrm{A}() \mathrm{B}() \mathrm{C} .[\mathrm{D} .1) \_2\right) \_3\right) \_4\right)$ \\
\hline 40. donkey & $\left.\left.\left.\mathrm{A}() \mathrm{B}() \mathrm{C} \cdot(\mathrm{D} .1) \_2\right) \_3\right) \_4\right)$ \\
\hline 41. rigid & $\left.\left.\left.\mathrm{A}() \mathrm{B}() \mathrm{C} .[\mathrm{D} .1) \_2\right) \_3\right) \_4\right)$ \\
\hline 42. uniquely & $\left.\left.\left.\mathrm{A}() \mathrm{B}() \mathrm{C} .[\mathrm{D} .1) \_2\right) \_3\right) \_4\right)$ \\
\hline 43. schematically & $\left.\left.\left.\left.\mathrm{A}() \mathrm{B}() \mathrm{C} . \mathrm{D}_{1} \cdot 1\right) \_2\right) \_3\right) \_4\right)$ \\
\hline 44. bubble & $\left.\left.\left.\mathrm{A}() \mathrm{B}() \mathrm{C} \cdot[\mathrm{D} \cdot 1) \_2\right) \_3\right) \_4\right)$ \\
\hline 45. curer & $\left.\left.\left.\mathrm{A}() \mathrm{B}() \mathrm{C} .[\mathrm{D} .1) \_2\right) \_3\right) \_4\right)$ \\
\hline 46. diplomatic & $\left.\left.\left.\mathrm{A}() \mathrm{B}() \mathrm{C} \cdot[\mathrm{D} \cdot 1) \_2\right) \_3\right) \_4\right)$ \\
\hline 47. jet & $\left.\left.\left.\left.\mathrm{A}() \mathrm{B}() \mathrm{C} . \mathrm{D}_{1} \cdot 1\right) \_2\right) \_3\right) \_4\right)$ \\
\hline 48. 10bby & $\left.\left.\left.\mathrm{A}() \mathrm{B}() \mathrm{C} .[\mathrm{D} .1) \_2\right) \_3\right) \_4\right)$ \\
\hline 49. oval & $\left.\left.\left.\left.\mathrm{A}() \mathrm{B}() \mathrm{C} . \mathrm{D}_{2} \cdot 1\right) \_2\right) \_3\right) \_4\right)$ \\
\hline 50. quivery & $\left.\left.\left.\mathrm{A}() \mathrm{B}() \mathrm{C} .[\mathrm{D} .1) \_2\right) \_3\right) \_4\right)$ \\
\hline 51. species & $\mathrm{A}() \mathrm{B}() \mathrm{C} . \quad \mathrm{D} .1) \quad 2) \quad 3) \quad 4)$ \\
\hline
\end{tabular}




\begin{tabular}{|c|c|}
\hline 52. unexpectedly & $\left.\left.\left.\left.\mathrm{A}() \mathrm{B}() \mathrm{C} . \mathrm{D}_{-} \mathrm{D} \cdot 1\right) \_2\right) \_3\right) \_4\right)$ \\
\hline 53. audit & $\left.\left.\left.\mathrm{A}() \mathrm{B}() \mathrm{C} .(\mathrm{D} \cdot 1) \_2\right) \_3\right) \_4\right)$ \\
\hline 54. caress & $\left.\left.\left.\mathrm{A}() \mathrm{B}() \mathrm{C} \cdot[\mathrm{D} \cdot 1) \_2\right) \_3\right) \_4\right)$ \\
\hline 55. clog & $\left.\left.\left.\mathrm{A}() \mathrm{B}() \mathrm{C} \cdot[\mathrm{D} \cdot 1) \_2\right) \_3\right) \_4\right)$ \\
\hline 56. descent & $\left.\left.\left.\mathrm{A}() \mathrm{B}() \mathrm{C} \cdot[\mathrm{D} \cdot 1) \_2\right) \_3\right) \_4\right)$ \\
\hline 57.doze & $\left.\left.\mathrm{A}\left(\mathrm{)} \mathrm{B}(\mathrm{)} \mathrm{C} \cdot-\mathrm{D} \cdot 1) \_2\right) \_3\right) \_4\right)$ \\
\hline 58. foul & $\left.\left.\left.\mathrm{A}() \mathrm{B}() \mathrm{C} \cdot[\mathrm{D} \cdot 1) \_2\right) \_3\right) \_4\right)$ \\
\hline 59. irrigate & $\left.\left.\left.\mathrm{A}() \mathrm{B}() \mathrm{C} \cdot[\mathrm{D} \cdot 1) \_2\right) \_3\right) \_4\right)$ \\
\hline 60.passionate & $\left.\mathrm{A}() \mathrm{B}() \mathrm{C} \cdot \mathrm{D}_{-1} \mathrm{D} \cdot 1\right)$ \\
\hline 61. receptive & $\left.\left.\left.\mathrm{A}() \mathrm{B}() \mathrm{C} .(\mathrm{D} \cdot 1) \_2\right) \_3\right) \_4\right)$ \\
\hline 62. reel & $\left.\left.\mathrm{A}\left(\mathrm{)} \mathrm{B}() \mathrm{C} \cdot[\mathrm{D} \cdot 1) \_2\right) \_3\right) \_4\right)$ \\
\hline 63. stall & $\left.\left.\left.\mathrm{A}() \mathrm{B}() \mathrm{C} \cdot[\mathrm{D} \cdot 1) \_2\right) \_3\right) \_4\right)$ \\
\hline 64. stereo & $\left.\left.\left.\mathrm{A}() \mathrm{B}() \mathrm{C} \cdot(\mathrm{D} \cdot 1) \_2\right) \_3\right) \_4\right)$ \\
\hline 65. strive & $\left.\left.\left.\mathrm{A}() \mathrm{B}() \mathrm{C} \cdot[\mathrm{D} .1) \_2\right) \_3\right) \_4\right)$ \\
\hline 66. wring & $\left.\left.\left.\mathrm{A}() \mathrm{B}() \mathrm{C} \cdot(\mathrm{D} \cdot 1) \_2\right) \_3\right) \_4\right)$ \\
\hline 67. thermal & 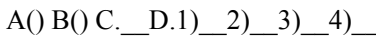 \\
\hline 68. verdict & $\left.\left.\left.\mathrm{A}() \mathrm{B}() \mathrm{C} \cdot(\mathrm{D} \cdot 1) \_2\right) \_3\right) \_4\right)$ \\
\hline 69 . veto & $\left.\mathrm{A}() \mathrm{B}() \mathrm{C} . \quad \mathrm{D} .1) \_2\right)(3)$ \\
\hline 70. tavern & $\mathrm{A}() \mathrm{B}() \mathrm{C} . \quad \mathrm{D} .1) \quad 2) \quad 3) \quad 4)$ \\
\hline
\end{tabular}

\section{Copyrights}

Copyright for this article is retained by the author(s), with first publication rights granted to the journal.

This is an open-access article distributed under the terms and conditions of the Creative Commons Attribution license (http://creativecommons.org/licenses/by/3.0/). 